\title{
AN ARTICLE V CONVENTION OF STATES AS A CONSTITUTIONAL INITIATIVE AT THE FEDERAL LEVEL
}

\author{
Tomasz Wieciech \\ Institute of Political Science and International Relations \\ of the Jagiellonian University in Kraków \\ e-mail: twieciech@wp.pl
}

\begin{abstract}
Under Article V, Congress shall call a convention on the application of two-thirds of state legislatures. Convention of states has never been called, despite a number of attempts. An Article $\mathrm{V}$ convention has become a specific form of constitutional initiative at the federal level. It serves primarily as a convenient way to pressure Congress to propose an amendment and not to actually make federal legislature call a convention. Such a use of an Article V convention has not been very effective and only rarely proved to be successful.
\end{abstract}

Keywords: United States, constitutional amendment procedure, convention of states

\section{INTRODUCTION}

Article V of the U.S. Constitution sets the amendment procedure. It reads as follows:

The Congress, whenever two thirds of both Houses shall deem it necessary, shall propose Amendments to this Constitution, or, on the Application of the Legislatures of two thirds of the several States, shall call a Convention for proposing Amendments, which, in either Case, shall be valid to all Intents and Purposes, as Part of this Constitution, when ratified by the Legislatures of three fourths of the several States, or by Conventions in three fourths thereof, as the one or the other Mode of Ratification may be proposed by the Congress $(\ldots)^{1}$.

* This research was funded by Narodowe Centrum Nauki (NCN). Grant no. 2011/01/D/HS5/01757.

1 Article V also provides that "that no Amendment which may be made prior to the Year One thousand eight hundred and eight shall in any Manner affect the first and fourth Clauses in 
This short provision establishes two methods to amend the Constitution. The procedure is - at least in general terms - rather straightforward. Basically, it is a two-step process ${ }^{2}$. First, an amendment must be proposed. This can be done either by Congress, where the majority of two-thirds in both houses is required, or by a convention called by Congress when applied to by the similar majority of state legislatures. Second, an amendment passed by Congress or proposed by a convention must be subsequently approved by the qualified majority of states representative bodies. Amendment may be ratified either by legislatures or by conventions. Approval of these bodies in at least three-fourths of the states is required, which means that as the current number of states is fifty, thirty-eight of them must approve. The federal legislature makes decision concerning the mode of ratification. It makes no difference whether an amendment is proposed by Congress or by a convention. In other words, Congress may decide that an amendment proposed by Congress itself should be ratified by state conventions and one proposed by a convention called under Article $\mathrm{V}$ should be ratified by state legislatures, or - of course - the other way around.

Language of Article $\mathrm{V}$ suggests that the first method to amend the Constitution, that is one where Congress proposes amendments, should be the ordinary way to make occasional alterations in the text, should they be requested or required. There is also little doubt that this was exactly what the Framers intended. In practice, the congressional method has become not only the usual but literally the only way to propose amendments to the Constitution. All thirty-three amendments sent to the states for ratification had been passed by Congress. Convention for proposing amendments - known simply as an Article $\mathrm{V}$ convention or convention of states - has never been called.

It is easy to dismiss the convention of states as one of the - allegedly numerous - relics of the Constitution. To do so would be, however, to overlook its sig-

the Ninth Section of the first Article; and that no State, without its Consent, shall be deprived of its equal Suffrage in the Senate". The first clause is now of only historical importance. The second provides additional protection for another provision of the Constitution that guarantees every state equal number of Senators. It stipulates that should an amendment to the Constitution be proposed to the effect that one or more states would be entitled to greater number of delegates in the Senate than the rest, to become a part of the Constitution such an amendment would have to be ratified by all state legislatures or conventions in all states. U.S. Const. art. V.

2 It should be noted, however, that the convention method is somewhat more cumbersome as it involves two additional stages before an amendment can even be proposed. The first one is the preparation of applications by state legislatures. This requires that at least thirty-four of them adopt proper resolutions addressed to Congress. Successful completion of this initial step triggers another. When required number of applications under article V of the Constitution reaches the Capitol Hill, federal legislature is obliged to call a convention for proposing amendments. It is, however, unclear what this obligation actually involves. Specifically, it is at least questionable whether, beside prescribing time and place of convention, Congress can also make decisions concerning the number of delegates from each state, the mode of their appointment or the requirements they should meet, i.e. of age, citizenship or residency. 
nificant role in the American constitutional system. In the absence of constitutional initiative provision at the federal level, convention clause of Article $\mathrm{V}$ has showed itself to be a convenient alternative. Even though no attempt to call a convention has yet been successful, on more than one occasion the process itself proved to be effective in pressuring federal legislators to act on particular propositions of constitutional amendments, despite their initial opposition. Continuing relevance of the convention method to amend the Constitution lies therefore not in its ability to bypass Congress altogether but rather in its potential to successfully push for constitutional amendments that enjoy popular support, against the opposition from the federal political elites [Rogers 2007].

This article has three parts. Part I examines the original meaning of an Article V convention method. Part II reviews most significant attempts to call a convention of states in the past. Part III discusses current appeal of the process. The article argues that given the grassroots origins of the most recent efforts to make a use of convention of states method to amend the Constitution, it has been effectively transformed into an original form of constitutional initiative. The article seeks to explain the reason and consequences of this transformation. Accordingly, the following questions will be discussed: what was the original meaning of Article $\mathrm{V}$ convention method; how it had been used in the past; what is its current appeal?

\section{THE ORIGINAL MEANING OF AN ARTICLE V CONVENTION METHOD}

At the early stages of deliberations on the Constitutional Convention, the idea of convention of states as the proper method to amend the Constitution met with general approval. Initially, the prevailing opinion was that this should be the sole mode to make alterations to the fundamental law. In the report presented to the Convention on August 6, Committee of Detail proposed that "On the application of the Legislatures of two thirds of the States in the Union, for an amendment of this Constitution, the Legislature of the United States shall call a Convention for that purpose" [Farrand 1911]. Later on, the conception of a convention was, however, dropped altogether'. In the final draft of Article V laid before the Convention on September 12 it was left entirely to Congress to propose amendments

3 James Madison was largely responsible for that. When the Convention decided to reconsider Article XIX of the draft - one that would later become Article V of the Constitution - on September 10 he attacked the idea of a convention of states as a method to amend the instrument, warning of the dangers that resulted from the vagueness of the term. He was concerned with number of issues regarding the procedure, such as "How was a Convention to be formed? by what rule decide? what the force of its acts"? In his opposition to the proposed amendment process he was supported by Alexander Hamilton who thought that it would be best if Congress was to be empowered to call a convention "whenever two thirds of each branch should concur". Ultimately, Madison moved to take up a new proposition of article under consideration. It was passed without further debate, 
to the Constitution; on its own initiative - the majority of two-thirds in both Houses was required - or on the application of two-thirds of state legislatures. In the debate that followed, George Mason took a stand against this proposition. He argued that according to the scheme, proposing amendments would depend either immediately or ultimately on Congress, which he thought would mean that "no amendments of the proper kind would ever be obtained by the people, if the Government should become oppressive" [Farrand 1911]. Convention of states provision was added to Article $\mathrm{V}$ of the Constitution in direct response to arguments raised by critics like Mason. Proper alteration to the original draft was approved unanimously, without opposition.

Article $\mathrm{V}$ received only scarce attention in state ratifying conventions [Maier 2010]. In fact, it was probably one of the least controversial parts of the Constitution [Lash 1994]. Nevertheless, on those rare occasions where it was discussed, however briefly, debate was concentrated mostly on the feasibility of making alterations to the Constitution by the use of the amendment procedure. Here, opponents of the instrument raised objections, arguing that it would be virtually impossible to make any amendments to the Constitution given that not only the majority of two-thirds was required in both Houses of Congress but also that any proposed amendment would have to be ratified by as much as three-fourths of states. Patrick Henry - one of the most ferocious adversaries of the Constitution made powerful argument against Article $V$ in the Virginia convention on exactly this ground. For him, there was no real difference between two methods to amend the Constitution because either way a very small minority could obstruct any attempt to better the fundamental law [Elliot 1836].

All in all, not much had been said on the floors of ratifying conventions about the convention of states process. There is no doubt, however, that it was perceived by members first and foremost as a safeguard against possible encroachments on the part of the federal government. The ratifiers did see "the Article V convention process as a constitutional provision offering the states the power to protect themselves from the evils of a central government" [Castro 1986]. But to grasp the meaning of the convention method it is important to understand what exactly did "state" mean in this context. Because it could have meant two very different things: state governments or the people of several states. For all we know both meanings were well-founded and the preference for one or the other stemmed only from differences in political principles; from different beliefs that one held and different expectations that one had towards the government. It should be remembered though that not only was it perfectly reasonable to think of a "state" as of the people in their sovereign capacity but that at the time such views were probably in the majority. With this in mind it is fair to say that the fact that state legislatures were responsible for applying Congress to call a convention for pro-

nine states being in favor, and two days later presented to the Convention in the final draft of the Constitution [Farrand 1911]. 
posing amendments to the Constitution did not mean that it was a matter between two orders of governments. Quite the contrary, it might have suggested that the people would be involved in the process, albeit indirectly. It might very well have been expected that representatives in state legislatures would act, if not only than at least primarily, when petitioned to do so by their constituents.

One additional point needs to be made here. Even though the Constitution established direct representation of the people in Congress, given their proximity state legislatures were still predisposed to act as their agent and represent their interests against the central government. So, if state legislatures are responsible for applying Congress to call a convention to propose amendments to the Constitution it can very well mean that they will act in this regard on behalf of the people themselves and on their command. As James Iredell explained in the North Carolina convention, should Congress not deem amendments necessary "and yet [they] be generally wished for by the people, two thirds of the legislatures of the different states may require a general convention for the purpose, in which case Congress are under the necessity of convening one" [Elliot 1836] $]^{4}$.

Those who commented on the convention of states provision usually emphasized that under Article V of the Constitution, Congress would be obliged to call a convention whenever the required number of states so demanded. "The national rulers" wrote Alexander Hamilton "whenever nine States concur will have no option upon the subject". He further explained that the words of Article V were "peremptory. The Congress 'shall call a convention'. Nothing in this particular is left to the discretion of this body" [Hamilton 1788]. The early commentators also believed that this method to amend the Constitution would be used rarely, if at all, being a kind of the last bulwark against the government, to be used only in extraordinary circumstances. St. George Tucker in his widely acclaimed View of the Constitution of the United States observed that convention of states mode "will probably never be resorted to, unless the federal government should betray symptoms of corruption, which may render it expedient for the states to exert themselves in order to the application of some radical and effectual remedy" [Tucker 1803].

Few conclusions can be drawn from the brief survey of historical evidence regarding the original meaning of an Article $\mathrm{V}$ convention. First, legislative history of Article $\mathrm{V}$ suggests that the purpose of a convention of states provision was to deprive the federal government of the full control over the amendment process. Second, at the time, this method to amend the Constitution came as close as it gets to constitutional initiative. Of early state constitutions only Georgia's constitution of 1777 allowed the people to directly initiate constitutional change. It provided in Article LXIII that alterations to the constitution could be made only in a convention called by the legislature when requested to do so by "petitions from the majority of the counties, and the petitions in each county [had been] signed by a majority

\footnotetext{
${ }^{4}$ Underline is added.
} 
of voters in each county". Legislature would specify "the alterations to be made, according to the petitions preferred to the assembly by the majority of the counties as aforesaid" [Thorpe 1909]. This provision clearly resembles the one that can be found in Article $\mathrm{V}$ of the federal Constitution, the only two differences being that in the latter the people were not allowed to petition Congress directly - which is understandable given the size of the federal republic and the nature of the federal form of government - and that amendments approved by convention would not have to be subsequently ratified, the difference which can also be explained by federalism. Finally, it was expected that convention of states method would be used only if the congressional mode proved ineffective. As noted by Russell S. Caplan "this Congress-convention sequence was an inherent expectation if not a requirement, common sense dictating that the easier method of proposal be tried first" [Caplan 1988]. Such sentiment grew even stronger after First Congress had swiftly passed twelve amendments in response to requests of several ratifying conventions.

\section{PAST ATTEMPTS TO CALL A CONVENTION OF STATES}

The first attempt to use the Article V convention provision was made right after the adoption of the Constitution. Movement to call a second constitutional convention attracted some support in a number of states but in the end only New York and Virginia applied for a convention under Article V. The applications were the aftermath of ratification debate when many delegates to ratifying conventions insisted that the Constitution should be immediately amended. The most radical critics of the new government even argued for a second constitutional convention. Some state conventions ratified the Constitution with suggested amendments, the understanding being that they would be promptly adopted. However, most of those who wished the Constitution to be altered, one way or another, thought it best that Congress should propose amendments. The prevailing opinion at the time was that this method to amend the Constitution was more preferable. The applications of New York and Virginia presented the minority position. Interestingly, going against dominating sentiments, Virginia legislature claimed that the convention mode was actually more practicable, "the slow forms of Congressional discussion and recommendation, if indeed they should ever agree to any change, would (...) be less certain of success" [Kaminski et al. 1993].

In the first hundred years after the ratification of the Constitution, there was only one other significant attempt to call a convention of states. In the early 1830 s, amidst the high tension between the federal government and the southern states resulting from the federal tariffs policy, three state legislatures decided to apply Congress for a convention of states under Article V. South Carolina led the way, followed by Alabama and Georgia. South Carolina's application, passed 
on December 18, 1832 was the first submitted to Congress since $1789^{5}$. Instead of requesting that specific amendments be proposed by the convention of states, South Carolina's legislature expected that the gathering would "consider and determine such questions of disputed power, as have arisen between the States of this confederacy and the General Government" [Caplan 1988]. Even if convention had been called, such expectation could not have been met since it was clearly unconstitutional. The Article V convention was definitely not the proper body to decide constitutional disputes between the state and federal governments. Both Georgia and Alabama requested amendments concerning specific issues but also left it to a convention to propose additional, should it find them necessary.

There were few other attempts to call a convention of states, shortly before and during the Civil War, but none of them was of any consequence. At the turn of the $20^{\text {th }}$ century, the campaign for popular elections of United States senators transformed the Article $\mathrm{V}$ method to amend the Constitution and turned it into an original form of constitutional initiative. The use of a convention of states process in this particular campaign was innovative in two different ways. First, the states decided to start the process without an actual desire for holding a convention. Instead, they hoped that it could create an additional and powerful incentive for Congress to acquiesce to an explicit proposition of constitutional amendment. Second, the states coordinated their actions on an unprecedented scale. Pennsylvania legislature was the first one to establish a standing committee specifically to coordinate efforts with other states for obtaining amendment. Similar committees were later established in Georgia, Arkansas and Oklahoma, but it was the Pennsylvania committee that led the way. It even prepared an application form, which it sent to other states. Although some of them decided not to use it, deviations from the standard formula were not common [Natelson 2010]. It was not long before the number of applications sent to Congress neared the required number. On most accounts, it took thirteen years - from 1899 to 1912 - to fill thirty-one applications. If only one more had been sent, Congress would have been obliged to call a convention of states [Caplan 1988].

Of all historical attempts to call a convention of states under Article $\mathrm{V}$ of the Constitution, only two, in addition to campaign for direct elections, nearly approached the constitutional threshold of two-thirds applications from two-thirds of the states. There were more attempts, however, and even though - except for the two - none came close to pass the constitutional threshold, few of them were of some significance. Between 1906 and 1916, twenty-six states applied for a convention of states to propose an amendment that would prohibit polygamy. Five states adopted applications under Article V to pursue the repeal of the Eighteenth Amendment. By 1952, at least thirteen states petitioned Congress to call a convention to propose the federal income tax limitation at twenty-five percent [Diamond 1981].

5 Georgia's and Alabama's legislatures approved Article V applications on December 20, 1832 and January 12, 1833, respectively. 
First one of the two major efforts to use the Article V convention method was the campaign to propose an amendment that would overturn the 1964 decision of the Supreme Court in Reynold v. Sims, which required states to apportion seats in both houses of their legislatures solely on the population basis. According to the proposition, one house of the state legislature would have been exempted from the "one man-one vote" rule. The effort was led by senator Everett Dirksen who turned his attention to the Article V convention method after he had failed to attract necessary support for the amendment in Congress. According to one author, "Dirksen's campaign for a constitutional convention [sic!] was a calculated effort to force congressional action as much as it was an attempt actually to convene a gathering like the Philadelphia convention of 1787" [Kyvig 2002]. Whatever the case may have been, the campaign to prevent reapportionment revolution was almost successful. If only one more states had sent application, Congress would have been obliged to act. However, the total tally had reached only thirty-three states. There were controversies regarding the count. The validity of some applications were questioned by the opponents of a convention of states in Congress. The quarrel might have been of some consequence if the number of state applications had actually reached thirty-four. Because it did not happen, it will suffice to note that applications were numerous and that all of them had been adopted in only five years span, between 1964 and 1969. It says a lot about the significance of this particular use of an Article V convention method. More on controversies surrounding the process in Bonfield [1968].

In the $20^{\text {th }}$ century, there was only one more attempt to call a convention of states that nearly succeeded. Between 1975 and 1983, thirty-two states applied for a convention to propose an amendment that would mandate balanced federal budgets. This was probably the most intense campaign to date. In the first four years, the total number of applications reached thirty. The momentum of the movement organized and led mainly by the National Taxpayers Union came in 1979 with the number of applications at thirty and the important endorsement by the California governor Jerry Brown. But then it was successfully stopped by growing opposition. Its last accord was the approval of the amendment by the Senate in August 1982 (in the House of Representatives the proposition was, however, buried) and the thirty second application adopted by Missouri legislature in March 1983.

\section{CURRENT APPEAL OF THE CONVENTION OF STATES}

The interest in the Article $\mathrm{V}$ convention method has revived in the last decade. Although a number of advocacy groups launched campaigns to call a convention of states to address variety of propositions, only three of them attracted significant support: Balanced Budget Amendment Task Force (BBAT), campaigning for a convention of states to consider a balanced budget amendment; Convention of States Project $(\mathrm{CoS})$ that coordinates efforts to call a convention to propose 
amendments to impose fiscal restraints on the federal government, to limit the power and jurisdiction of the federal government and to limit the terms of office for its officials and for members of Congress, and Wolf Political Action Committee (Wolf PAC) that advocates an amendment that would reform political campaign finance in the United States.

The three initiatives are not equally popular nor successful in their efforts. BBAT claims that at present they have secured twenty-eight out of thirty-four necessary state applications. This count is somewhat problematic though. Apparently, it includes all pending balanced budget applications without regard to their contemporaneity or specific wording. In other words, all the applications that had been adopted at some point and have not yet been rescinded are deemed by the organization as valid as long as the subject matter is a balanced budget amendment. It is, however, questionable if Congress will regard them as effective under Article V of the Constitution should it be claimed by the BBAT that the total tally is at thirty-four, which is actually not improbable given that each year the campaign is actively targeting those states that are most likely to support its cause. Of twenty-eight applications, fifteen has been passed in the last eight years and twelve between 1975 and 1983.

Since 2014, twelve state legislatures have adopted applications under Article $\mathrm{V}$ promoted by the Convention of States Project, four of them in the last year alone. Moreover, according to the organization, in early 2018, in ten states applications were passed in one chamber of the legislature and in another eighteen states there was pending legislation to that effect. Launched in 2013 the CoS campaign is well-organized and much coordinated endeavor. To minimize the risk that the ultimate tally might be challenged, states are encouraged to use the standard application prepared by the Convention of States Project. Accordingly, states use similar language in their applications, and simply, as in the case of Texas,

\footnotetext{
apply to Congress to call a convention under Article V of the United States Constitution for the limited purpose of proposing one or more amendments to the constitution to impose fiscal restraints on the federal government, to limit the power and jurisdiction of the federal government, and to limit the terms of office of federal officials and members of Congress (...).
}

Except for the last one, the proposed subject matters to be considered at a convention of states are described in general terms, which means that more than one amendment could be proposed to address them. Many has been suggested, including: term limits for members of Congress, Supreme Court Justices and federal bureaucrats; balanced budget amendment; requirement of a photo ID to vote; to bar the federal government from involvement in healthcare and education; to prohibit federal bureaucrats imposing regulations; to remove authority of the federal government over state energy policy and land issues within state borders.

The campaign follows the footsteps of the Tea Party Movement and similarly relies heavily on the grassroots activism. The $\mathrm{CoS}$ encourages its sympathizers 
to actively pressure their state legislators to win their support for a convention of states. Aligned with the conservative wing of the Republican Party it has received endorsements from prominent political figures. Among those who publicly expressed support for the Convention of States Project are former vice-presidential candidate Sarah Palin, former governor of Florida Jeb Bush, Sens. Rand Paul and Marco Rubio and governor of Texas Gregg Abbott. Despite the fact that the CoS receives support from Republican politicians and appeal mainly to Republican legislators in the states, still it distances itself from both political parties and especially from their leadership. In its nature it has been without any doubt an anti-establishment movement.

Although politically they position themselves on completely opposing sides, the Wolf PAC shares the grassroots and anti-establishments characteristics with the CoS. The initiative was launched in 2011 by Cenk Uygur, a left-wing activist and political commentator in response to the Supreme Court's 2010 decision in Citizens United v. Federal Electoral Commission, in which the Court found that financial restrictions imposed on corporations that aimed to limit their ability to support political broadcast in elections were unconstitutional because they violated freedom of speech protected under the First Amendment. According to the Wolf PAC, the Court's decision should be overruled by an amendment to the Constitution "that will establish elections which are free of the corrupting influence of money in our political system and fair enough that any citizen can run for office, not just millionaires and their allies". The organization relies on grassroots activism and volunteers working with state legislators. Up to date, seven states have passed applications to call a convention of states to address the issue of political campaign finance. They do not use standard application form so the resolutions adopted in particular states differ from one another. For instance, California in 2014, applied Congress

to call a constitutional convention [sic!] pursuant to Article V of the United States Constitution for the sole purpose of proposing an amendment to the United States Constitution that would limit corporate personhood of campaign finance and political speech and would further declare that money does not constitute speech and may be legislatively limited,

whereas Illinois in 2015, declared in its application that it

sees a need for a convention to propose amendments in order to address concerns such as those raised by the decision of the United States Supreme Court in Citizens United v. Federal Electoral Commission and related cases and events, including long before or afterward, or for a substantially similar purpose.

Although they do not necessarily have the same political goals, the most significant of the current advocates of a convention of states have many things in common. Not only are they not aligned with what has been called the political establishment, but they actively act against it. Their rhetoric is populist and strongly anti-establishment. They reject traditional partisan politics and present general 
distrust in politicians. All of them have clear grassroots credentials. They were launched by political activists not engaged directly in everyday partisan politics. They promote constitutional amendments that are popular among the general population and yet cannot find enough support of the political elites in Congress. They all state that their true goal is to make Congress call a convention of states, but it is likely that they would be satisfied if they succeeded in pushing federal legislature to propose amendments on its own.

The renewed interest in an Article V convention of states is one of the most intriguing developments in American politics of the last decade or so. Even if nothing will come out of it, it is still important since at least it signifies serious dissatisfaction with the federal government and federal political elites. To be sure, it is not unprecedented. Current situation is in a way similar to the one from the turn of the $19^{\text {th }}$ and $20^{\text {th }}$ century as well as from the 1960s and 1970s. Few differences, however, should be noted. The current appeal of a convention of states is definitely strongest among conservative voters. Most constitutional amendments advocated by Article $\mathrm{V}$ convention campaigns are part of the conservative agenda. It shows that current political consensus in the United States leans toward the "left of the center" side of the political spectrum. Furthermore, it seems that never before the general distrust in government was the most important motivation in pursue of a convention of states. Finally, the renaissance of a convention of states is a reminder to the political elites of the powerfulness of the truly democratic, bottom-up political process.

\section{CONCLUSIONS}

Convention of states under Article V of the Constitution has never been called. Nevertheless, it has been hardly a dormant clause, especially since the turn of the $19^{\text {th }}$ and $20^{\text {th }}$ century. Its use in the last hundred years has effectively transformed it into an original form of constitutional initiative at the federal level. The process serves to promote certain constitutional amendments in order - at the minimum - to influence Congress to propose them itself.

A brief survey of amendments advocated by Article $\mathrm{V}$ convention campaigns over the last hundred years or so shows that their goal was usually either to curb the federal government (balanced budget, federal income tax limitation, general limitation of federal power and jurisdiction), to change its structure and operation (popular election of senators, term limits for members of Congress) or to defend the powers of the states against the perceived encroachments by the federal government (reapportionment). In all these cases, the nature of constitutional change desired by the general population went against the grind and was, in a sense, anti-government, that is the proposed amendments were of such a kind that they could hardly attract massive support from the functionaries of the federal government. 
In addition, as it has been already mentioned, Article $\mathrm{V}$ convention campaigns are strongly grassroots movement, fueled by anti-government and anti-establishment sentiments. This also makes them similar to constitutional initiative which, after all, is supposed to provide mechanism for the citizenry to actively engage in constitutional politics and prevent monopolizing it by the governing elites.

The record of a convention of states method as a constitutional initiative at the federal level is rather poor. The only instance when it actually took a significant part - if not decisive - in the effort to push a constitutional amendment through Congress was of course the Seventeenth Amendment saga. Assessing the role played by a convention of states campaign one should be careful though. As noted by Caplan,

although the simultaneous accumulation of thirty-one applications for direct election and its proposal by Congress suggests that the drive played a key role, there remains no evidence that the convention threat by itself forced the Senate to approve the amendment. At least as influential was the growing quota of senators, chosen by popular vote (...) [Caplan 1988].

There is some truth to it, that with regard to applications under Article V of the Constitution, "Congress is successfully lobbied only when it wants to be" [Diamond 1981]. Neither in the case of reapportionment nor balanced budget amendments the nearly required number of state petitions was enough to force Congress to take action. On the other hand, at least in the last two decades, amendments advocated by convention of states campaigns were the most frequently introduced in Congress. As of April 16, 2018, since 1999, balanced budget amendment has been introduced 134 times, amendment to reform campaign finance -72 times and term limits amendment - 69 times [Desilver 2018]. These amendments are also among those who reached the vote on the floor of at least one chamber. Most recently, on April 12, 2018, House of Representatives voted down yet another balanced budget amendment. Two hundred and thirty-three members voted in favor and 184 against, well short of a two-thirds majority.

The experience shows that convention of states can operate successfully as a constitutional initiative only when certain conditions are met: the proposed amendment must be popular and its popularity cannot be only momentary but must attract attention of the people over an extended period of time; the action must be swift, which means that significant number of state legislature must adopt applications under Article $\mathrm{V}$ in relatively short period of time in order to create a real "threat" that a convention of states will have to be called; amendment needs to be supported by a substantial part of the political elites, large enough to form a nucleus of the required two-thirds majority in both chambers of Congress. 
Tytul: Konwencja stanów na podstawie artykułu V Konstytucji jako szczególna forma inicjatywy ludowej w sprawie zmiany Konstytucji w Stanach Zjednoczonych Ameryki

Streszczenie: Zgodnie z postanowieniami artykułu V Konstytucji, konwencja w celu zaproponowania poprawek do Konstytucji jest zwoływana przez Kongres na wniosek dwóch trzecich legislatur stanowych. W dotychczasowej praktyce nigdy nie doszło do zastosowania omawianej procedury. Alternatywny tryb zmiany konstytucji przez zwołanie konwencji przekształcił się na gruncie praktyki ustrojowej w oryginalną formę inicjatywy ludowej w sprawie zmiany dokumentu. Podejmując działania zmierzające do zwołania konwencji, inicjatorzy dążą bowiem najczęściej do wymuszenia na Kongresie uchwalenia stosownej propozycji poprawki do Konstytucji. Skuteczność takiego stosowania trybu konwencji jest niewielka.

Slowa kluczowe: Stany Zjednoczone Ameryki, procedura zmiany konstytucji, konwencja

\section{REFERENCES}

1. Bonfield, A.E., 1968, The Dirksen Amendment and the Article V Convention Process, "Michigan Law Review", 66 (5), pp. 949-1000.

2. Caplan, R.S., 1988, Constitutional Brinkmanship. Amending the Constitution by National Convention, Oxford University Press, New York-Oxford, pp. 45, 50, 63-65.

3. Castro, D., 1986, A Constitutional Convention: Scouting Article Five's Undiscovered Country, "University of Pennsylvania Law Review", 134 (4), pp. 949-950.

4. Desilver, D., 2018, Proposed amendments to the U.S. Constitution seldom go anywhere, http:// www.pewresearch.org (access: 30.04.2018).

5. Diamond, A.S., 1981, A Convention for Proposing Amendments: The Constitution Other's Method, "Publius. The Journal of Federalism", 11 (3/4), pp. 122-123.

6. Elliot, J. (ed.), 1836, The Debates in the Several State Conventions on the Adoption of the Federal Constitution, Vols. 3, 4, Washington, pp. 49-50, 177.

7. Farrand, M. (ed.), 1911, The Records of Federal Convention of 1787, Vol. 2, Yale University Press, New Haven, pp. 188, 558-559, 629.

8. Hamilton, A., 1788 [2003], Federalist no. 85. In: The Federalist Papers, Signet Classic, New York.

9. Kaminski, J.P, Saladino, J.G., Leffler, R., Schoenleber, Ch.H., Carlson, M. (ed.), 1993, The Documentary History of the Ratification of the Constitution, Vol. 10. Ratification of the Constitution by the States: Virginia (3), State Historical Society of Wisconsin, Madison, p. 1766.

10. Kyvig, D.E., 2002, Everett Dirksen's Constitutional Crusades, "Journal of the Illinois State Historical Society", 95 (1), p. 79.

11. Lash, K.T., 1994, Rejecting Conventional Wisdom: Federalist Ambivalence in the Framing and Implementation of Article V, "American Journal of Legal History", 38 (2), p. 214.

12. Maier, P., 2010, Ratification. The People Debate the Constitution, 1787-1788, Simon and Schuster, New York.

13. Natelson, R.G., 2010, Learning from Experience: How the States Used Article V Applications in America's First Century (Part 2 in a 3 Part Series), Policy Brief, No. 10-06, pp. 18-21.

14. Rogers, J.K., 2007, The Other Way to Amend the Constitution: The Article V Constitution Amendment Process, "Harvard Journal of Law \& Public Policy", 30 (3), p. 1020.

15. Thorpe, F.N. (ed.), 1909, The Federal and State Constitutions, Vol. 2, Government Printing Office, Washington, p. 785.

16. Tucker St., G. 1803 [1999], View of the Constitution of the United States, [in:] View of the Constitution of the United States With Selected Writings, Liberty Fund, Indianapolis, p. 306. 